(c) American Dairy Science Association, 2007.

\title{
Effects of Dietary Vitamin C on Neutrophil Function and Responses to Intramammary Infusion of Lipopolysaccharide in Periparturient Dairy Cows
}

\author{
W. P. Weiss ${ }^{1}$ and J. S. Hogan \\ Department of Animal Sciences, Ohio Agricultural Research and Development Center, The Ohio State University, Wooster 44691
}

\begin{abstract}
Neutrophil function and the severity and incidence of mastitis in dairy cows is related to the intake of many antioxidant nutrients. Because vitamin $\mathrm{C}$ is the major water-soluble antioxidant in mammals, we examined the effect of dietary vitamin $\mathrm{C}$ on neutrophil function and responses to intramammary infusion of lipopolysaccahride (LPS) in periparturient dairy cows. At $2 \mathrm{wk}$ before anticipated calving, Holstein cows were fed diets that provided 0 (16 cows) or 30 (15 cows) g/d of supplemental vitamin $\mathrm{C}$ (phosphorylated ascorbic acid). Treatments continued until $7 \mathrm{~d}$ after cows received an infusion of $10 \mu \mathrm{g}$ of LPS into one quarter of the mammary gland (on average, this occurred $32 \mathrm{~d}$ postcalving). Supplementation of vitamin C increased plasma concentrations of vitamin $\mathrm{C}$ at calving, but no differences were observed in samples taken $24 \mathrm{~h}$ postinfusion. Concentrations of vitamin $\mathrm{C}$ in milk ( $24 \mathrm{~h}$ postinfusion) and in neutrophils (calving and $24 \mathrm{~h}$ postinfusion) were not affected by treatment, but vitamin $\mathrm{C}$ concentrations in neutrophils isolated from milk were about 3 times greater than concentrations in blood neutrophils. The LPS infusion did not alter concentrations of vitamin C in plasma or milk, suggesting that the LPS model did not produce the same effects as a bacterial infection of the mammary gland with respect to antioxidant effects. Supplemental vitamin C had no effect on neutrophil phagocytosis or bacterial kill. Dietary vitamin C reduced the milk somatic cell count but did not affect the febrile response or milk production following LPS infusion.
\end{abstract}

Key words: antioxidant, mastitis, neutrophil, vita$\min \mathrm{C}$

\section{INTRODUCTION}

A clear link exists between the proper supplementation of many nutrients (e.g., $\mathrm{Cu}$, Se, vitamin E) involved

Received June 9, 2006.

Accepted September 18, 2006

${ }^{1}$ Corresponding author: weiss.6@osu.edu in antioxidant systems of cows and the severity and incidence of mastitis (Smith et al., 1984; Erskine et al., 1989; Weiss et al., 1997; Scaletti et al., 2003). Ascorbic acid is the most abundant and probably most important water-soluble antioxidant in mammals (Sauberlich, 1994). Even though cows can synthesize vitamin C and vitamin $\mathrm{C}$ is not a required nutrient for dairy cows, data are accumulating that suggest vitamin $\mathrm{C}$ is related to mastitis. Cows with mastitis have lower concentrations of vitamin $\mathrm{C}$ in the plasma and milk (Weiss et al., 2004; Kleczkowski et al., 2005) and the severity of clinical signs is correlated with the magnitude of the decrease in concentrations (Weiss et al., 2004). Subcutaneously injected vitamin $\mathrm{C}$ may have therapeutic value for cows with mastitis (Naresh et al., 2002; Ranjan et al., 2005); however, the methodologies used in previous studies have produced equivocal results. The severity of some clinical signs were reduced when cows were injected with vitamin $\mathrm{C}$ following an intramammary infusion of LPS (Chaiyotwittayakun et al., 2002). Intracellular concentrations of ascorbic acid increase dramatically when human neutrophils are activated (Washko et al., 1993), perhaps to protect the cells and surrounding tissues from damage caused by reactive oxygen species (ROS) generated by the oxidative burst of the neutrophils. This may be one explanation for the link between vitamin $\mathrm{C}$ and mastitis. The effects of dietary supplementation of vitamin $\mathrm{C}$ on mastitis and neutrophil function of dairy cows are not known.

We hypothesized that feeding a form of vitamin $\mathrm{C}$ that has been shown to increase plasma concentrations of vitamin $\mathrm{C}$ in dairy cows would improve neutrophil function via its antioxidant properties and would lessen the severity of LPS-induced mastitis. Because antioxidant status appears to be compromised in the peripartum period (Goff and Stabel, 1990; Weiss et al., 1990) the experiment was conducted with peripartum cows. The objectives of this experiment were to determine whether 1) LPS-induced mastitis reduced milk and plasma concentrations of vitamin C; 2) supplemental dietary vitamin $\mathrm{C}$ affected concentrations of vitamin $\mathrm{C}$ in blood and milk neutrophils; and 3) supplemental dietary vitamin $\mathrm{C}$ during the peripartum period im- 
Table 1. Ingredient and nutrient composition of diets fed during the last $10 \mathrm{~d}$ of gestation (prepartum) and in early lactation

\begin{tabular}{lcc}
\hline Composition & Prepartum & Lactation \\
\hline Orchardgrass hay (early head) & 36.0 & - \\
Alfalfa silage & 22.0 & 37.0 \\
Corn silage & 5.0 & 15.0 \\
Corn grain, ground & 24.3 & 25.7 \\
Soybean meal, 44\% of CP & 5.0 & 9.4 \\
Soybean hulls & 4.1 & 7.5 \\
Distillers grains with solubles & 1.5 & 3.0 \\
Fat (animal-vegetable blend) & 0.5 & 0.9 \\
Mineral mix & 1.00 & 1.25 \\
Vitamin-trace mineral mix & \\
\hline
\end{tabular}

${ }^{1}$ Mineral mix for prepartum diet: $13 \%$ dicalcium phosphate, $27 \%$ limestone, $15 \%$ magnesium oxide, $12 \%$ magnesium sulfate, and $33 \%$ trace mineral salt. For lactation diet: $25 \%$ dicalcium phosphate, $45 \%$ limestone, $6 \%$ magnesium oxide, $32 \%$ trace mineral salt, and $17 \%$ sodium bicarbonate.

${ }^{2}$ For prepartum diet, mix provided (per kg of diet DM): 86 IU of vitamin $\mathrm{E} / \mathrm{kg}, 1,940 \mathrm{IU}$ of vitamin $\mathrm{D}, 8,940 \mathrm{IU}$ of vitamin $\mathrm{A}, 12 \mathrm{mg}$ of $\mathrm{Cu}$ (from copper sulfate), $0.3 \mathrm{mg}$ of Se (sodium selenate), and 37 $\mathrm{mg}$ of $\mathrm{Zn}$ (zinc sulfate). For lactation diet, mix provided (per $\mathrm{kg}$ of diet DM): 4,260 IU of vitamin A, 1,160 IU of vitamin D, 25 IU of vitamin $\mathrm{E} / \mathrm{kg}, 9 \mathrm{mg}$ of $\mathrm{Cu}$ (from copper sulfate), $0.3 \mathrm{mg}$ of Se (sodium selenate), and $89 \mathrm{mg}$ of $\mathrm{Zn}$ (zinc sulfate).

proved neutrophil function and reduced the severity of clinical signs following an LPS infusion into the mammary gland.

\section{MATERIALS AND METHODS}

\section{Cows and Treatments}

At $60 \mathrm{~d}$ before anticipated calving, dry Holstein cows and heifers were moved to a common free-stall pen and fed a diet formulated to meet the requirements of dry cows (NRC, 2001). Animals ( $\mathrm{n}=34$ ) were blocked based on parity (cows or heifers) and expected calving date into groups of 2 ( 11 blocks of cows and 6 blocks of heifers were assigned to the experiment). At 2 wk before anticipated calving, animals were moved to individual box stalls and once daily were fed a diet formulated for lategestation animals (Table 1 ) that provided 0 or $30 \mathrm{~g} /$ d of actual supplemental vitamin C (phosphorylated ascorbic acid, Rovimix Stay-C 35; DSM Nutritional Products, Parsippany, NJ). That rate of supplementation has been shown to elevate plasma vitamin C concentrations (Weiss, 2001). Supplementation was started 2 wk before anticipated calving because of our work with dietary vitamin $\mathrm{E}$ (another antioxidant). On d 1 postcalving, cows were switched to lactation diets (Table 1) that provided 0 or $30 \mathrm{~g} / \mathrm{d}$ of supplemental vitamin $\mathrm{C}$ (cows remained on the same vitamin $\mathrm{C}$ treatment throughout the experiment). For both prepartum and lactating cows, the vitamin $\mathrm{C}$ was mixed into a concentrate that was fed at $1 \mathrm{~kg} / \mathrm{d}$ before the remaining diet was offered. At approximately $3 \mathrm{~d}$ postcalving, cows were moved from box stalls to tie stalls and were fed the lactation diets once daily. Cows were milked twice daily, with milk yields measured electronically, and were fed once daily and DMI was measured starting at $3 \mathrm{~d}$ postcalving until $7 \mathrm{~d}$ after the mammary gland infusion of LPS (average $39 \mathrm{~d}$ postcalving).

\section{Blood Sampling}

Blood samples were taken via the tail vein into tubes containing heparin and into tubes containing EDTA (10 and $50 \mathrm{~mL}$ of blood, respectively) on 1) 1 to $3 \mathrm{~d}$ before cows were moved to box stalls [averaging $13 \mathrm{~d}$ (SD = 5.7) before actual calving], 2) the first full Thursday following calving (averaging $4 \mathrm{~d}$ after calving, $\mathrm{SD}=1.9$ ), and 3) $24 \mathrm{~h}$ after cows received the mammary gland infusion of LPS (averaging $32 \mathrm{~d}$ after calving, $\mathrm{SD}=9.4$ ). Within 30 min of collection, tubes containing heparized blood were centrifuged $\left(1,000 \times g\right.$ at $4^{\circ} \mathrm{C}$ for $\left.15 \mathrm{~min}\right)$ and the plasma was used for vitamin $\mathrm{C}$ analysis. Neutrophils were isolated from the blood samples containing EDTA (Hogan et al. (1992).

\section{Neutrophil Function}

Neutrophil phagocytosis and intracellular kill of Escherichia coli 487 (originally isolated from a clinical case of bovine mastitis) were determined in blood neutrophils isolated from the calving sample. Phagocytosis and intracellular kill of bacteria by neutrophils were measured by modifications of the fluorochrome assay described by Goldner et al. (1983). Neutrophils were collected and bacteria prepared as described by Hogan et al. (1992). Briefly, bacteria were cultured to the stationary phase of growth, washed, and opsonized in $10 \%$ heat-inactivated serum for $20 \mathrm{~min}$. Suspensions of neutrophils and opsonized bacteria were added to incubation tubes in a ratio of 1:2 (neutrophils:bacterial colonyforming units) and incubated at $100 \mathrm{rpm}$ for $90 \mathrm{~min}$. The phagocytic index was calculated as the average number of bacteria phagocytosed per neutrophil. Intracellular kill was determined as [number of dead phagocytosed bacteria/(number of live + number of dead intracellular bacteria) $\times 100$ ]. The percentage of neutrophils phagocytizing was calculated as the number of neutrophils with at least one intracellular bacteria divided by the total number of neutrophils $\times 100$. All assays were in duplicate and conducted blind relative to laboratory personnel having prior knowledge of cow or treatment.

\section{LPS Infusion}

At an average of $32 \mathrm{~d}$ postcalving ( $\mathrm{SD}=9$ ), either the right or left front mammary quarter from each cow was 
infused with LPS via the teat canal. Infusions were 3 $\mathrm{h}$ after the morning milking (0200), and only uninfected quarters were infused. Infection status was determined by microbiological culture of samples taken 7,2 , and 1 $\mathrm{d}$ prior to infusions. Concentrated LPS was purchased (E. coli O26:B6; Sigma Chemical Co., St. Louis, MO), diluted in PBS, and sterilized by passage through 0.2$\mu \mathrm{m}$ pore filters. The challenge inoculum was $10 \mu \mathrm{g}$ of LPS in $10 \mathrm{~mL}$ of PBS. Milk samples were collected from infused and noninfused quarters at 2, 4, 6, 8, 10, 12, $24,48,72$, and $96 \mathrm{~h}$ after infusion to determine the speed and magnitude of intramammary neutrophil response. The SCC per milliliter of milk was determined by a Bentley Somatocount 150 milk somatic cell counter (Bentley Instruments, Inc., Chaska, MN). Samples from clinical quarters were diluted 1:10 and 1:50 (milk:PBS, vol/vol) for counting. Data were expressed as $\log _{10}$ SCC per milliliter of milk. Rectal temperatures were measured immediately prior to infusion and at each time that quarter foremilk samples were collected postinfusion.

Milk from the infused quarter and milk composited from the 3 noninfused quarters (approximately equal volume from each quarter) were sampled $24 \mathrm{~h}$ postinfusion for vitamin $\mathrm{C}$ analysis. Neutrophils were isolated from milk from the infused quarter $24 \mathrm{~h}$ postinfusion by the procedures described by Grasso et al. (1990), except that cells were washed and stored in Hanks balanced salt solution instead of PBS and assayed for total vitamin $\mathrm{C}$.

\section{Vitamin C Analyses}

Immediately after plasma was separated from cells, $1 \mathrm{~mL}$ of a solution containing $1.12 \% \mathrm{~m}$-phosphoric acid and $0.05 \%$ dithiothreitol was added to $1 \mathrm{~mL}$ of plasma to convert any dehydroascorbic acid (DHAA) into ascorbic acid (i.e., total vitamin C). Ascorbic acid was quantified by HPLC (Timmons et al., 2001). The milk samples collected $24 \mathrm{~h}$ postinfusion were treated identically to plasma and assayed for total vitamin C. An additional plasma sample taken at $24 \mathrm{~h}$ post-LPS was analyzed for ascorbic acid by omitting the dithiothreitol from the solution. The difference between total vitamin $\mathrm{C}$ and ascorbic acid was DHAA.

Immediately after blood and milk neutrophils were separated, a pellet containing, on average, $1.6 \times 10^{8}$ neutrophils was dissolved in $1 \mathrm{~mL}$ of a solution containing $1.12 \% \mathrm{~m}$-phosphoric acid and $0.05 \%$ dithiothreitol. The mixture was allowed to sit for $30 \mathrm{~min}$ at room temperature $\left(\sim 25^{\circ} \mathrm{C}\right)$, vortexed, and placed in a freezer $\left(-20^{\circ} \mathrm{C}\right)$ for $2 \mathrm{~h}$. The samples were then rapidly thawed in hot tap water, vortexed, and placed in a freezer overnight. The following morning, samples were rapidly thawed, frozen for $2 \mathrm{~h}$, and then rapidly thawed again. Glass beads $(3 \mathrm{~mm})$ were added and the sample was vortexed for $1 \mathrm{~min}$. The mixture was placed in centrifugal filters (Ultrafree-Cl filters, UFCA LTK; Millipore Corp., Bedford, MA) and centrifuged for $30 \mathrm{~min}$ at $12,000 \times g$ at $4^{\circ} \mathrm{C}$. The supernatant was immediately assayed for total vitamin C using the same HPLC procedure as used for plasma. Blood neutrophils collected on $-10 \mathrm{~d}$, calving, and $24 \mathrm{~h}$ postinfusion, and milk neutrophils collected $24 \mathrm{~h}$ postinfusion were assayed for total vitamin C.

\section{Statistical Analyses}

Of the 34 animals assigned to the experiment, data from 3 cows were not used ( 2 cows on the vitamin $\mathrm{C}$ treatment and 1 control). One cow (vitamin $\mathrm{C}$ treatment) calved $9 \mathrm{~d}$ before expected and therefore received the treatment on only $1 \mathrm{~d}, 1$ cow (control) had severe metritis, and 1 cow (vitamin C) had several metabolic disorders shortly after calving. Production and neutrophil function data were analyzed with PROC MIXED (SAS Institute, 2004). The model included block (random), treatment (fixed), and error. Repeated-measures data (vitamin $\mathrm{C}$ concentrations in plasma and blood neutrophils, and SCC, body temperature, and milk production during the LPS infusion experiment) were analyzed with PROC MIXED. The model included block (random), treatment (fixed), time (repeated, fixed), treatment by time interaction (fixed), and error. The analyses for vitamin $\mathrm{C}$ concentrations in plasma and blood neutrophils were conducted with and without (before treatment began) the precalving values. The SLICE option was used to compare treatment means within each time point and to compare time means within each treatment. Vitamin $\mathrm{C}$ concentrations in blood neutrophils were compared with those in milk neutrophils using a model that included block (random), dietary treatment (fixed), source of neutrophil (repeated within cow and fixed), treatment by source interaction, and error. The same model was used to compare concentrations of vitamin $\mathrm{C}$ in milk from the quarter that received LPS to a composite sample from the 3 quarters that were not infused (source of milk replaced the source of neutrophils).

\section{RESULTS AND DISCUSSION}

Milk production and DMI were not affected by treatment. During the lactation period (calving until the day before the mammary gland infusion), milk production averaged 39.6 and $38.5 \mathrm{~kg} / \mathrm{d}(\mathrm{SEM}=1.5 ; P>0.5)$ and DMI averaged 18.8 and $19.1(\mathrm{SEM}=0.5 ; P>0.5)$ for control and vitamin C-supplemented cows, respectively (data not shown). 
Table 2. Effect of dietary vitamin C, physiological stage, and intramammary infusion of LPS on concentrations of vitamin C in plasma and blood neutrophils ${ }^{1}$

\begin{tabular}{llll}
\hline Item & Control & Vitamin C & SEM \\
\hline Plasma, $\mu \mathrm{mol} / \mathrm{L}$ & & & \\
$\quad$-13 d & 22.2 & $22.9^{\mathrm{a}}$ & 1.3 \\
Calving & $23.4^{*}$ & $26.5^{* \mathrm{~b}}$ & 1.2 \\
24 h post-LPS & $24.4^{\mathrm{b}}$ & $25.4^{\mathrm{b}}$ & 1.3 \\
Neutrophils, pmol/10 ${ }^{6}$ cells & & & \\
-13 d & $19.6^{\mathrm{a}}$ & $20.9^{\mathrm{a}}$ & 2.4 \\
Calving & $29.9^{\mathrm{b}}$ & $32.7^{\mathrm{b}}$ & 3.9 \\
24 h post-LPS & $25.3^{\mathrm{b}}$ & $28.6^{\mathrm{b}}$ & 2.2 \\
\hline
\end{tabular}

${ }^{\mathrm{a}, \mathrm{b}}$ Means within a column and sample type (plasma or neutrophil) differ $(P<0.05)$.

${ }^{1}$ Cows were fed 0 or $30 \mathrm{~g} / \mathrm{d}$ of supplemental vitamin $\mathrm{C}$ starting 13 $\mathrm{d}$ before anticipated calving $(-13 \mathrm{~d})$. The $-13-\mathrm{d}$ sample was taken before dietary treatments were started. The 24-h post-LPS sample was taken $24 \mathrm{~h}$ after an infusion of LPS into one quarter of the mammary gland (average DIM $=32$ ).

* Means within a row differ $(P<0.06)$.

\section{Plasma Vitamin C Concentrations}

Effect of Time. Plasma was sampled precalving (average of $13 \mathrm{~d}$ before actual calving and before treatments were imposed), shortly after calving (average of $4 \mathrm{~d}$ ), and $24 \mathrm{~h}$ after the intramammary infusion of LPS (average of $32 \mathrm{~d}$ postcalving). Therefore, the time effect included changes in physiological status (i.e., late gestation, early postpartum, and established lactation), the effect of LPS infusion, and the effect of vitamin C supplementation. When all 3 time points were included in the statistical analysis, the concentration of vitamin $\mathrm{C}$ in plasma was affected by time $(P<0.08)$, but based on the SLICE option analysis, time affected plasma vitamin $\mathrm{C}$ concentrations differently for the 2 treatments (Table 2). For control cows, concentrations were not affected by time $(P>0.40)$, but for supplemented cows, plasma concentrations before calving were less than concentrations postcalving $(P<0.07)$. Supplementation did not start until after the first sample was collected; therefore, this time effect likely represents a response to supplementation. When the initial samples were excluded from the statistical analysis, no time effects were observed $(P>0.80)$ for either treatment. To further investigate possible effects of stage of gestation and lactation, plasma vitamin $\mathrm{C}$ data were plotted against actual day relative to calving (Figure 1) and no effect of day was evident. Other studies have reported that plasma concentrations of vitamin $\mathrm{C}$ do not change during the peripartum period (Santos et al., 2001; Padilla et al., 2005). In this respect, vitamin $\mathrm{C}$, a major water-soluble antioxidant, differs from vitamin $\mathrm{E}$, a major lipid-soluble antioxidant, because plasma concentrations of $\alpha$-tocopherol are markedly reduced in the peripartum period (Goff and Stabel, 1990; Weiss et al.,
1990). If plasma concentrations are an indicator of vitamin C status, parturition does not appear to negatively affect vitamin $\mathrm{C}$ status.

The time effect also would include any effect of the LPS infusion. We anticipated that plasma vitamin C concentrations would decrease following the LPS infusion, because cows that have either a natural (Kleczkowski et al., 2005) or experimentally given (Weiss et al., 2004) bacterial infection of the mammary gland have substantially (40 to 50\%) lower concentrations of vitamin $\mathrm{C}$ in plasma than cows that are not infected. Because we did not collect a sample immediately before infusion, we cannot unequivocally state that the LPS infusion did not decrease plasma vitamin C. However, the time profile of plasma vitamin $\mathrm{C}$ concentrations (Figure 1) essentially mirrors that of a previous study (Padilla et al., 2005) in which early-lactation cows were not infused with LPS and did not have mastitis. One possible reason the plasma concentration of vitamin $\mathrm{C}$ did not decrease following LPS infusion is that the severity of the inflammatory response was less than that observed with a bacterial infection. The body temperature and milk production responses (discussed below) were mild compared with clinical responses following an E. coli infusion (Weiss et al., 2004). Kleczkowski et al. (2005), however, reported lower plasma concentrations of vitamin $\mathrm{C}$ in cows that had bacterial infections of the mammary gland but had normal body temperature and no gross clinical signs of illness. Another possible reason for the different results between this study and previous work is that a $10-\mu \mathrm{g}$ infusion of LPS caused different responses than a bacterial infection. A likely reason for the decrease in vitamin $\mathrm{C}$ concentrations during a bacterial infection of the mammary gland is that vitamin $\mathrm{C}$ is destroyed by ROS that are produced by the oxidative burst of neutrophils during phagocytosis and bacterial kill. Intramammary infusion with LPS $(25 \mu \mathrm{g})$ causes increased production of ROS by milk neutrophils (Mehrzad et al., 2001), but the production of ROS induced by a $10-\mu \mathrm{g}$ infusion of LPS may have been substantially less than when a bacterial infection is present.

Effect of Vitamin C Supplementation. Cows fed supplemental vitamin $\mathrm{C}$ had greater $(P<0.06)$ concentrations of vitamin $\mathrm{C}$ in plasma sampled $4 \mathrm{~d}$ after calving but not $(P>0.55)$ in samples collected $24 \mathrm{~h}$ after the LPS infusion (Table 2). At $4 \mathrm{~d}$ postcalving, plasma vitamin $\mathrm{C}$ concentrations were about $17 \%$ greater in cows fed supplemental vitamin $\mathrm{C}$ than in the control cows. Midlactation dairy cows fed the same form and amount of supplemental vitamin $\mathrm{C}$ for $28 \mathrm{~d}$ had plasma vitamin $\mathrm{C}$ concentrations that were $25 \%$ greater than the controls (Weiss, 2001). The reasons supplemental vitamin $\mathrm{C}$ did not affect concentrations of vitamin $\mathrm{C}$ in 


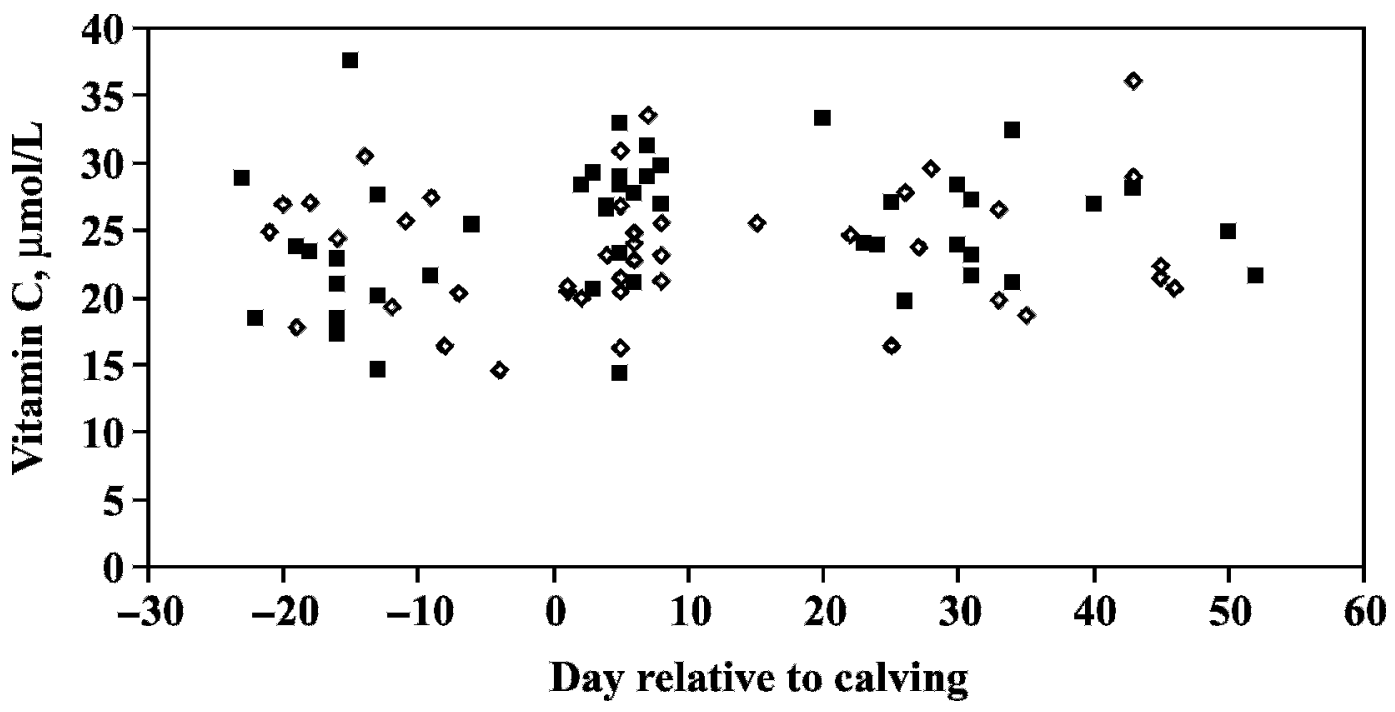

Figure 1. Concentrations of vitamin $\mathrm{C}$ in plasma from cows during the peripartum period. Cows were fed 0 (open symbols) or $30 \mathrm{~g} / \mathrm{d}$ (solid symbols) of supplemental vitamin C. Symbols clustered between -22 and $-7 \mathrm{~d}$ represent samples taken before supplementation started; symbols clustered between 1 and $7 \mathrm{~d}$ represent samples taken shortly after calving; and symbols clustered between 15 and $52 \mathrm{~d}$ represent samples taken $24 \mathrm{~h}$ after intramammary infusion of LPS.

plasma collected $24 \mathrm{~h}$ post-LPS are not clear. On average, cows were fed supplemental vitamin $\mathrm{C}$ for 20 and $49 \mathrm{~d}$ when the calving and post-LPS samples were taken, and perhaps the duration of supplementation was a factor. The form of vitamin $\mathrm{C}$ used in this experiment is degraded by ruminal bacteria, albeit at a much slower rate (half-life of $6.9 \mathrm{vs} .3 .5 \mathrm{~h}$ ) than ascorbic acid (Macleod et al., 1999b), and perhaps some rumen bacteria increased their ability to utilize the compound. Another possible explanation is the regulation of plasma concentrations of ascorbic acid via alterations in gut absorption, liver synthesis, and kidney excretion. In humans, elevated intake of vitamin $\mathrm{C}$ reduces gut $\mathrm{ab}-$ sorption of ascorbic acid and increases kidney excretion (Levine et al., 1996). Some data collected from swine suggest that liver synthesis of ascorbic acid is reduced when vitamin C is supplemented (Mahan et al., 2004).

\section{Vitamin C Concentrations in Neutrophils}

Blood Neutrophils. The concentrations of vitamin $\mathrm{C}$ in blood neutrophils were not affected $(P>0.5)$ by treatment at any time point (Table 2). The lack of an effect of supplementation agrees with previous work conducted on dairy heifers (Macleod et al., 1999a). Time affected $(P<0.05)$ concentrations in neutrophils in both control and supplemented cows. This effect was caused by the lower concentrations observed in the samples collected before calving. There are several possible reasons why vitamin $\mathrm{C}$ concentrations in blood neutrophils were higher after calving than before calving. In iso- lated human blood neutrophils, the concentration of intracellular ascorbic acid increased linearly as the concentration of ascorbic acid in the incubation media increased from 5 to $15 \mathrm{~m} M$ (Washko et al., 1989). The trend toward increased concentrations of plasma vitamin $\mathrm{C}$ as cows progressed from late gestation to early lactation could have contributed to increased concentrations of vitamin $\mathrm{C}$ in neutrophils (the correlation between concentrations of vitamin $\mathrm{C}$ in plasma and blood neutrophils was $0.28, P<0.01$ ). Glucose at physiological concentrations reversibly inhibits uptake of ascorbic acid by human neutrophils (Washko and Levine, 1992). Late-gestation cows typically have higher concentrations of plasma glucose than early lactation cows (Studer et al., 1993), and this possibly could have contributed to the lower concentrations of vitamin $\mathrm{C}$ observed in late gestation compared with postpartum concentrations.

Milk Neutrophils. Supplementation of vitamin C did not affect $(P>0.25)$ vitamin $\mathrm{C}$ concentrations in neutrophils isolated from milk from the quarter infused with LPS (Figure 2). Milk neutrophils, however, had about 3 times greater $(P<0.01)$ concentrations of vitamin $\mathrm{C}$ than did neutrophils isolated from blood collected at the same time (Figure 2). When human neutrophils are activated, ascorbic acid is actively taken up and intracellular concentrations increase 10 - to 30 -fold compared with resting neutrophils (Washko et al., 1993; Wang et al., 1997). The increased uptake of ascorbic acid by activated neutrophils is likely a defense mecha- 


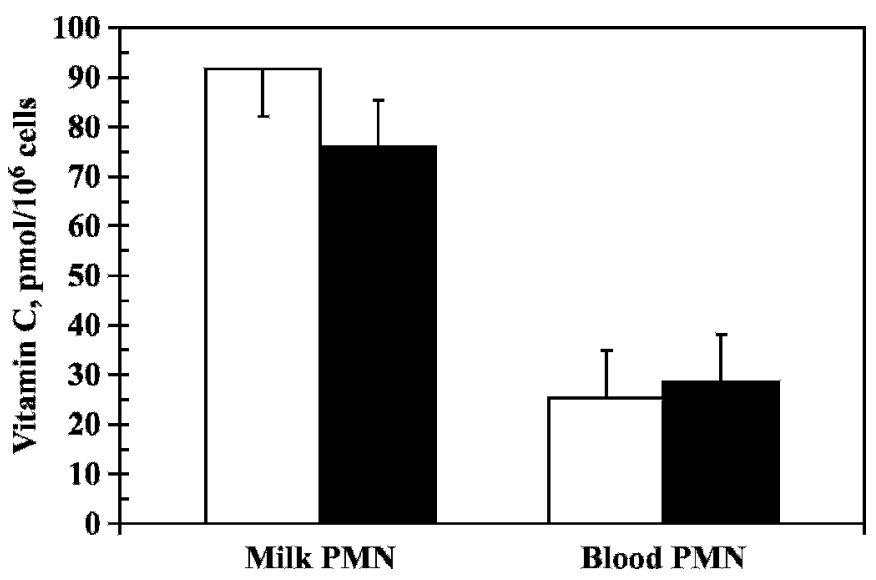

Figure 2. Effect of feeding 0 (open bars) or $30 \mathrm{~g} / \mathrm{d}$ of supplemental vitamin $\mathrm{C}$ (solid bars) on concentrations of vitamin $\mathrm{C}$ in polymorphonuclear neutrophils (PMN) isolated from milk (infused quarter) or blood. Samples were taken $24 \mathrm{~h}$ after intramammary infusion of LPS into one quarter. Vitamin $\mathrm{C}$ treatment had no effect $(P>0.5)$, but concentrations were greater $(P<0.01)$ in milk neutrophils than in blood neutrophils. Error bars indicate SE.

nism to protect the cell from oxidative damage caused by products of the oxidative burst (Wang et al., 1997).

The LPS infusion resulted in an influx of somatic cells (discussed below) into the infused quarter. During diapedesis, neutrophils become activated; therefore, the 3- to 4-fold difference in vitamin $\mathrm{C}$ concentrations between milk and blood neutrophils possibly was caused by activation.

Milk. The concentrations of ascorbic acid, DHAA, and vitamin $\mathrm{C}$ in milk taken $24 \mathrm{~h}$ after LPS infusion were not affected $(P>0.20)$ by dietary treatment (Table $3)$. Concentrations of those compounds also did not differ between milk collected from the quarter infused with LPS and milk collected from the healthy glands. The measured concentrations and the lack of an effect of supplemental dietary vitamin $\mathrm{C}$ were consistent with previous work (Weiss, 2001). However, the similar concentrations in milk from the infused quarter and
Table 4. Effect of dietary vitamin $\mathrm{C}$ on blood neutrophil function in dairy cows ${ }^{1}$

\begin{tabular}{llll}
\hline Item & Control & Vitamin C & SEM \\
\hline No. of cows & 16 & 15 & - \\
Positive neutrophils, \% & 92.2 & 91.7 & 0.40 \\
Intracellular bacteria/neutrophil, no. & 6.20 & 6.47 & 0.20 \\
Phagocytic index & 5.72 & 5.93 & 0.18 \\
Bacteria killed, \% & 81.4 & 80.0 & 1.1 \\
\hline
\end{tabular}

${ }^{1}$ Positive neutrophils contained at least one bacterium (Escherichia coli 487). Intracellular bacteria/neutrophil is the average number of bacteria in neutrophils that contained at least one bacterium. The phagocytic index was calculated by multiplying intracellular bacteria/ neutrophil by (positive neutrophils/100). Intracellular kill was determined as number of dead, phagocytized bacteria/(number of live + number of dead intracellular bacteria $) \times 100$. Treatment did not affect any measure $(P>0.25)$.

healthy quarters was not expected. The concentration of vitamin $\mathrm{C}$ in milk from a quarter infused with $E$. coli was about 50\% lower than milk from the quarters not infused (Weiss et al., 2004). Milk from cows with natural bacterial infection in at least one quarter had lower concentrations of vitamin $\mathrm{C}$ than did cows with no bacterial infection (Reineke et al., 1941). We also expected that the proportion of vitamin $\mathrm{C}$ that was DHAA would increase in the infused quarter (Weiss et al., 2004), but we actually observed a trend $(P<0.10)$ toward a lower proportion of DHAA in milk from the infused quarter (Table 3). As with plasma concentrations, the lack of a difference between vitamin $\mathrm{C}$ concentrations in milk from healthy quarters and LPS-infused quarters may have been caused by the experimental model. If production of ROS in the mammary gland was less with the dose of LPS used in this experiment compared with bacterial infection, the reduction in vitamin $\mathrm{C}$ concentrations would also be less.

\section{Neutrophil Function}

Treatment did not affect the function of neutrophils isolated from blood samples taken at calving (Table 4),

Table 3. Effect of dietary vitamin $\mathrm{C}$ on the concentrations of ascorbic acid, dehydroascorbic acid (DHAA), and total vitamin $\mathrm{C}$ in milk from healthy mammary quarters (composited) and in milk from the quarter infused with $\mathrm{LPS}^{1}$

\begin{tabular}{lcccccc}
\hline & \multicolumn{2}{c}{ Healthy quarters } & & \multicolumn{2}{c}{ Infused quarter } & \\
\cline { 2 - 3 } Item & Control & Vitamin $\mathrm{C}$ & & Control & Vitamin C & SEM \\
\hline Vitamin $\mathrm{C}, \mu \mathrm{mol} / \mathrm{L}$ & 107.6 & 110.3 & & 108.9 & 109.8 & 5.2 \\
Ascorbic acid, $\mu \mathrm{mol} / \mathrm{L}$ & 97.9 & 102.6 & & 100.4 & 104.8 & 5.4 \\
DHAA, $\mu \mathrm{mol} / \mathrm{L}$ & 9.7 & 7.8 & & 8.4 & 5.4 & 1.4 \\
DHAA, ${ }^{2} \%$ of vitamin C & 9.16 & 7.25 & & 8.01 & 5.12 & 1.34 \\
\hline
\end{tabular}

${ }^{1}$ Samples were taken $24 \mathrm{~h}$ after infusion. Treatment (vitamin C vs. control), quarter status (healthy vs. infused), and the treatment by status interaction were not significant $(P>0.20)$ for all measures except DHAA.

${ }^{2}$ Healthy quarters $>$ infused quarter $(P<0.10)$. 

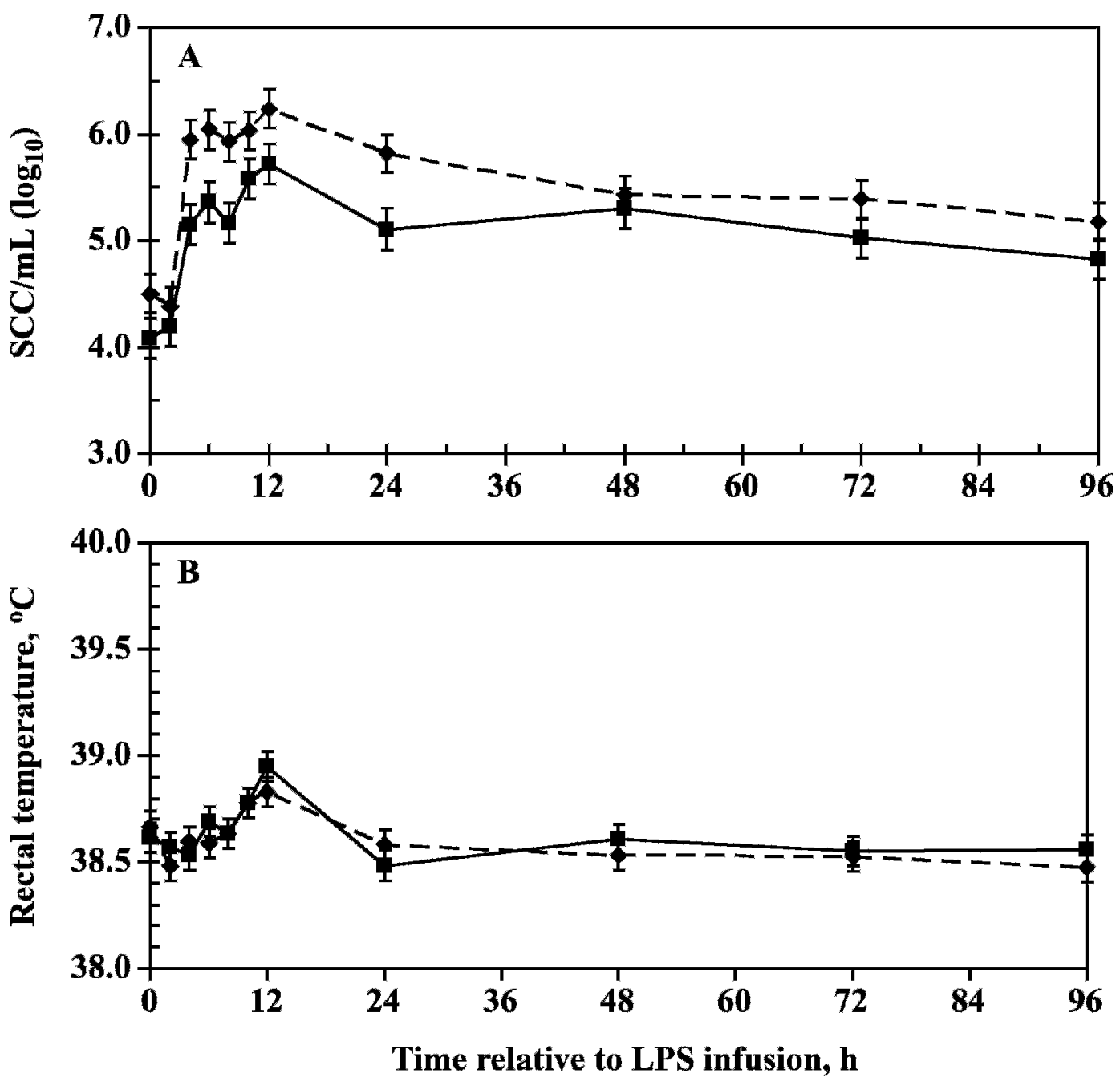

Figure 3. Effect of feeding 0 (dashed line) or 30 (solid line) g/d of supplemental vitamin C on milk SCC (A) and rectal temperature (B) following an intramammary infusion of LPS $(0 \mathrm{~h})$. Cows fed vitamin $\mathrm{C}$ had lower $(P<0.05)$ SCC from 4 to $24 \mathrm{~h}$ postinfusion. Error bars indicate SE.

similar to the lack of a treatment effect on vitamin C concentrations in neutrophils (Table 2). A subcutaneous injection ( $1 \mathrm{~d}$ before blood was sampled) of ascorbic acid $(20 \mathrm{mg} / \mathrm{kg}$ of BW) given to steers enhanced the neutrophil kill of Staphylococcus aureus (Roth and Kaeberle, 1985). Phagocytosis of latex particles by human neutrophils was enhanced when the cells were incubated in media containing ascorbic acid (Bergman et al., 2004). One possible reason for the different results is that the concentrations of ascorbic acid to which the neutrophils were exposed were likely much greater in the cited studies than in the current study. The concentration of vitamin $\mathrm{C}$ in plasma at calving was approximately $25 \mu M$, but in the in vitro study, cells were incubated in media containing approximately $1 \mathrm{~m} M$. Plasma concentrations of vitamin $\mathrm{C}$ were not measured in the steer study (Roth and Kaeberle, 1985), but plasma ascorbic acid concentrations increased to approximately $450 \mu M$ after dairy cows were given a single injection of ascorbic acid of approximately $40 \mathrm{mg} /$ $\mathrm{kg}$ of BW (Chaiyotwittayakun et al., 2002).

\section{Clinical Responses to LPS Infusion}

The intramammary infusion of LPS produced a mild inflammatory response. Body temperature peaked 12 $\mathrm{h}$ postinfusion at approximately $39^{\circ} \mathrm{C}$ (less than $0.5^{\circ} \mathrm{C}$ above basal) and returned to normal by $24 \mathrm{~h}$ postinfusion (Figure 3). Treatment did not affect the febrile response. The SCC response was affected by time $(P<$ $0.01)$, treatment $(P<0.01)$, and a time by treatment interaction $(P<0.05)$. Peak SCC occurred at $12 \mathrm{~h}$ for 
both treatments, but the SCC was lower $(P<0.01$ to $P$ $<0.05$ ) at $4,6,8,10,12$, and $24 \mathrm{~h}$ postinfusion for cows fed supplemental vitamin $\mathrm{C}$ than for control cows (Figure 3$)$. Daily DMI was not affected $(P>0.20)$ by treatment and no decrease was evident postinfusion (data not shown). Dry matter intake for all cows averaged $20.9 \mathrm{~kg} / \mathrm{d}$ for the $3 \mathrm{~d}$ before infusion, $20.9 \mathrm{~kg} / \mathrm{d}$ for the day of infusion, and $21.9 \mathrm{~kg} / \mathrm{d}$ for the $3 \mathrm{~d}$ postinfusion. Milk production during the infusion experiment was not affected by treatment but was reduced $(P<$ 0.05 ) by the infusion (data not shown). Average milk production for the day before, the day cows were infused, and the following day was 43.7 (SEM = 1.5), 40.5 $(\mathrm{SEM}=1.2)$, and $43.2(\mathrm{SEM}=1.2) \mathrm{kg} / \mathrm{d}$, respectively. The depression in milk production lasted only $24 \mathrm{~h}$ and averaged $7 \%$ compared with yields on the days before and after infusion.

In a previous experiment that also used LPS (Chaiyotwittayakun et al., 2002), intravenous administration of ascorbic acid after LPS infusion ( $25 \mathrm{~g}$ at 3 and $5 \mathrm{~h}$ postinfusion) did not affect the febrile response or SCC but did attenuate the reduction in milk yield following LPS. In that experiment, $100 \mu \mathrm{g}$ of LPS was used, and body temperature and SCC spikes were higher (approximately $41^{\circ} \mathrm{C}$ and $1 \times 10^{7}$ ) and loss in milk was greater (approximately 22\%) than in our study. The use of $10 \mu \mathrm{g}$ of LPS as an intramammary challenge simulates the clinical response typically seen in a mild clinical case of coliform mastitis (Barrett et al., 1997). One advantage of using a nonreplicating intramammary irritant such as LPS to measure the SCC response, compared with a live bacterial challenge, is that the LPS is delivered in a finite amount and the SCC response will not be confounded by the replication rate of bacteria because of noncellular growth factors in lacteal secretion. The speed of the SCC response was comparable between treatment groups following LPS infusion in the current trial; however, the number of cells recruited into the gland in response to the same amount of LPS was greater for nonsupplemented cows. The number of neutrophils entering the mammary gland depends on the amount of irritant (Paape et al., 1979), and excessive influx may relate to mammary damage because proteases released by neutrophils appear to be actively involved in udder tissue damage during mastitis (Mehrzad et al., 2005).

\section{ACKNOWLEDGMENTS}

Salaries and research support for this study were provided by state and federal funds appropriated to the Ohio Agricultural Research and Development Center, The Ohio State University. Additional funds were pro- vided by DSM Nutritional Products (Parsippany, NJ). Manuscript 23-06AS.

\section{REFERENCES}

Barrett, J. J., J. S. Hogan, W. P. Weiss, K. L. Smith, and L. M. Sordillo. 1997. Concentrations of $\alpha$-tocopherol after intramammary infusion of Escherichia coli or lipopolysaccharide. J. Dairy Sci. 80:2826-2832.

Bergman, M., H. Salman, M. Djaldetti, L. Fish, I. Punsky, and H Bessler. 2004. In vitro immune response of human peripheral blood cells to vitamins C and E. J. Nutr. Biochem. 15:45-50.

Chaiyotwittayakun, A., R. J. Erskine, P. C. Bartlett, T. H. Herdt, P. M. Sears, and R. J. Harmon. 2002. The effect of ascorbic acid and L-histidine therapy on acute mammary inflammation in dairy cattle. J. Dairy Sci. 85:60-67.

Erskine, R. J., R. J. Eberhart, P. J. Grasso, and R. W. Scholz. 1989. Induction of Escherichia coli mastitis in cows fed selenium-deficient or selenium-supplemented diets. Am. J. Vet. Res. 50:2093-2100.

Goff, J. P., and J. R. Stabel. 1990. Decreased plasma retinol, $\alpha-$ tocopherol, and zinc concentration during the periparturient period: Effect of milk fever. J. Dairy Sci. 73:3195-3199.

Goldner, M., H. Farkas-Himsley, A. Kormendy, and M. Skinner. 1983. Bacterial phagocytosis monitored by fluorescence and extracellular quenching: Ingestion and intracellular killing. Lab. Med. 14:291-294.

Grasso, P. J., R. W. Scholz, R. J. Erskine, and R. J. Eberhart. 1990. Phagocytosis, bactericidal activity, and oxidative metabolism of milk neutrophils from dairy cows fed selenium-supplemented and selenium-deficient diets. Am. J. Vet. Res. 51:269-274.

Hogan, J. S., W. P. Weiss, D. A. Todhunter, K. L. Smith, and P. S. Schoenberg. 1992. Bovine neutrophil responses to parenteral vitamin E. J. Dairy Sci. 75:399-405.

Kleczkowski, M., W. Klucinski, A. Shaktur, and J. Sikora. 2005. Concentration of ascorbic acid in the blood of cows with subclinical mastitis. Pol. J. Vet. Sci. 8:121-125.

Levine, M., C. Conry-Cantilena, Y. Wang, R. W. Welch, P. W. Wasko, K. R. Dhariwal, J. B. Park, A. Lazarev, J. F. Graumlich, J. King, and L. R. Cantilena. 1996. Vitamin C pharmacokinetics in healthy volunteers: Evidence for a recommended dietary allowance. Proc. Natl. Acad. Sci. USA 93:3704-3709.

Macleod, D. D., X. Zhang, J. J. Kennelly, and L. Ozimek. 1999a. Ascorbyl-2-polyphosphate as a source of ascorbic acid for dairy cattle. Milchwissenschaft 54:123-126.

Macleod, D. D., X. Zhang, J. J. Kennelly, and L. Ozimek. 1999b. Pharmokinetics of ascorbic acid and ascorbyl-2-polyphosphate in the rumen fluid of dairy cows. Milchwissenschaft 54:63-65.

Mahan, D. C., S. Ching, and K. Dabrowski. 2004. Developmental aspects and factors influencing the synthesis and status of ascorbic acid in the pig. Annu. Rev. Nutr. 24:79-103.

Mehrzad, J., C. Desrosiers, K. Lauzon, G. Robitaille, X. Zhao, and P. Lacasse. 2005. Proteases involved in mammary tissue damage during endotoxin-induced mastitis in dairy cows. J. Dairy Sci. 88:211-222.

Mehrzad, J., H. Dosogne, E. Meyer, and C. Burvenich. 2001. Local and systemic effects of endotoxin mastitis on the chemiluminescense of milk and blood neutrophils in dairy cows. Vet. Res. 32:131-144

Naresh, R., S. K. Dwivedi, D. Swarup, and R. C. Patra. 2002. Evaluation of ascorbic acid treatment in clinical and subclinical mastitis of Indian dairy cows. Asian-Australas. J. Anim. Sci. 15:905-911.

NRC. 2001. Nutrient Requirements of Dairy Cattle. 7th rev. ed. National Academy Press, Washington, DC.

Paape, M. J., W. P. Wergin, A. J. Guidry, and R. E. Pearson. 1979. Leukocytes-Second line of defense against invading mastitis pathogens. J. Dairy Sci. 62:135-153.

Padilla, L., K. Shibano, J. Inoue, T. Matsui, and H. Yano. 2005. Plasma vitamin $\mathrm{C}$ concentration is not related to the incidence of ketosis in dairy cows during the early lactation period. J. Vet. Med. Sci. 67:883-886. 
Ranjan, R., D. Swarup, R. Naresh, and R. C. Patra. 2005. Ameliorative potential of L-ascorbic acid in bovine clinical mastitis. Indian J. Anim. Sci. 75:174-177.

Reineke, E. P., E. R. Garrison, and C. W. Turner. 1941. The relation of mastitis to the level of ascorbic acid and certain other constituents in milk. J. Dairy Sci. 24:41-50.

Roth, J. A., and M. L. Kaeberle. 1985. In vivo effect of ascorbic acid on neutrophil function in healthy and dexamethasone-treated cattle. Am. J. Vet. Res. 46:2434-2436.

Santos, M. V., F. R. Lima, P. H. M. Rodrigues, S. B. M. Barros, and L. F. L. daFonseca. 2001. Plasma ascorbate concentrations are not correlated with milk somatic cell count and metabolic profile in lactating and dry cows. J. Dairy Sci. 84:134-139.

SAS Institute. 2004. SAS/STAT User's Guide, Version 9. SAS Institute Inc., Cary, NC.

Sauberlich, H. E. 1994. Pharmacology of vitamin C. Annu. Rev. Nutr. 14:371-391.

Scaletti, R. W., D. S. Trammell, B. A. Smith, and R. J. Harmon. 2003. Role of dietary copper in enhancing resistance to Escherichia coli mastitis. J. Dairy Sci. 86:1240-1249.

Smith, K. L., J. H. Harrison, D. D. Hancock, D. A. Todhunter, and H. R. Conrad. 1984. Effect of vitamin E and selenium supplementation on incidence of clinical mastitis and duration of clinical symptoms. J. Dairy Sci. 67:1293-1300.

Studer, V. A., R. R. Grummer, S. J. Bertrics, and C. K. Reynolds. 1993. Effect of prepartum propylene glycol administration on periparturient fatty liver in dairy cows. J. Dairy Sci. 76:29312939.
Timmons, J. S., W. P. Weiss, D. L. Palmquist, and W. J. Harper. 2001. Relationships among dietary roasted soybeans, milk components, and spontaneous oxidized flavor of milk. J. Dairy Sci. 84:24402449.

Wang, Y., T. A. Russo, O. Kwon, S. Chanock, and S. C. Rumsey. 1997. Ascorbate recycling in human neutrophils: Induction by bacteria. Proc. Natl. Acad. Sci. USA 94:13816-13819.

Washko, P., and M. Levine. 1992. Inhibition of ascorbic acid transport in human neutrophils by glucose. J. Biol. Chem. 267:2356823574 .

Washko, P., D. Rotrosen, and M. Levine. 1989. Ascorbic acid transport and accumulation in human neutrophils. J. Biol. Chem. 264:18996-19002.

Washko, P. W., Y. Wang, and M. Levine. 1993. Ascorbic acid recyling in human neutrophils. J. Biol. Chem. 268:15531-15535.

Weiss, W. P. 2001. Effect of dietary vitamin C on concentrations of ascorbic acid in plasma and milk. J. Dairy Sci. 84:2302-2307.

Weiss, W. P., J. S. Hogan, and K. L. Smith. 2004. Changes in vitamin $\mathrm{C}$ concentrations in plasma and milk from dairy cows after an intramammary infusion of Escherichia coli. J. Dairy Sci. 87:32-37.

Weiss, W. P., J. S. Hogan, K. L. Smith, and K. H. Hoblet. 1990. Relationships among selenium, vitamin E, and mammary gland health in commercial dairy herds. J. Dairy Sci. 73:381-390.

Weiss, W. P., J. S. Hogan, D. A. Todhunter, and K. L. Smith. 1997. Effect of vitamin E supplementation in diets with a low concentration of selenium on mammary gland health of dairy cows. J. Dairy Sci. 80:1728-1737. 